Liske Potgieter

Ms Liske Potgieter,

Music Department,

South Campus, PO Box

77000, NMM 6037;

E-mail: liskepotgieter@

gmail.com

\section{Zelda Potgieter}

Prof Zelda Potgieter,

Music Department,

South Campus, PO Box

77000, NMM 6037;

Email: zelda.potgieter@

nmmu.ac.za

DOI: http://dx.doi.

org/10.18820/24150479/

aa48i2.2

ISSN: ISSN 0587-2405

e-ISSN: 2415-0479

Acta Academica - 2016 48(2):

$48-75$

(c) UV/UFS

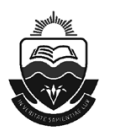

Deconstructing

Disney's divas: a critique of the singing princess as filmic trope

First submission: 2 June 2016

Acceptance: 8 December 2016

This article contributes to the discourse of the body and the voice in feminist psychoanalytic film theory by exploring the currently under-theorised notion of the singing body in particular, as this notion finds manifestation in Disney's Singing Princess as filmic trope. Analyses of vocal musical coding follow her trajectory across 13 Disney princess films to reveal deeper insight into what she sings, how she sings, and why she sing's. In this manner, it is argued, the Singing Princess gradually emerges from her genealogical roots as innamorata, a position of vocal corporealisation and diegetic confinement, to one wherein her voice assumes a position of authority over the narrative, and from one of absolute submissiveness and naïve obedience to a greatly enriched experience of her own subjectivity.

\section{Introduction}

Tropes are rhetorical devices that consist in senses other than their literal ones. While they are useful in rendering the unfamiliar more familiar, and while understanding figurative language is part of what it means to be a member of the culture in which such language is employed, tropes easily retreat to an 
undetected state - they are "not something we are normally aware of" (Lakoff and Johnson 1980: 3) - from which enigmatic position they are able to anchor us in dominant assumptions within our society, sustaining our tacit complicity almost beyond our volition. Should we wish to be sensitised to the pervasiveness of such assumptions, we are required to confront the tropes with which we live - to expose them, examine them, deconstruct them - so to consider a reality beyond the "cultural myths" (Barthes 1987: 115) that mould our everyday experience.

Walt Disney's Singing Princess is one such trope. In addition to cinema, she is ever present on our television screens, in our children's books, DVDs, home décor, clothing and toys'. From her first appearance as Snow White in 1938 to her most recent manifestation as Elsa in Frozen in 2013, she marks the Disney Company throughout its history as an "influential purveyor of gendered images" (Brocklebank 2000: 270), and on these grounds Disney's princess films have long been the subject of sustained scrutiny. In this article, a brief overview of the gist of this scrutiny provides a background against which attention is given to the trajectory that discourse takes from the point of view of the Disney princess as Singing Princess in particular. Typical vocal gestures from 13 Disney princess films are briefly analysed here in order to consider three things: how the princess sings, what she sings, and ultimately also why she sings ${ }^{2}$. These films are considered in three groups:

- The 'Perfect Princess' of Disney's first three princess films - Snow White and the Seven Dwarfs (1938), Cinderella (1950) and Sleeping Beauty (1959)

- The rebellious 'Renaissance Princess' of the period surrounding the 1990s. These include the princesses of The Little Mermaid (1989), Beauty and the Beast (1991), Aladdin (1992), Pocahontas (1995) and Mulan (1998). In addition, two later films, The Princess and the Frog (2009) and Tangled (2010), revert to the style of the princess films of the 1990s, and may be added to this group.

- The 'Deconstructed Diva' in Enchanted (2007), Brave (2012) and Frozen (2013).

1 The term "Disney Princess" is a media franchise owned by the Walt Disney Company, under which banner a host of products are marketed and sold worldwide. To date, 11 Disney characters have been officially inducted into the Disney Princess franchise, all animated characters who are either "from royal blood, or have married into royalty, or who fit the princess mythology". (http:// princess.disney.com/. Accessed 23 August 2014).

2 The delimitations of this study thus preclude a full analysis of the musical scores of the films in question. 
In so doing, this article seeks to contribute to the ever growing number of works devoted to discourses of the body in psychoanalytic film theory, but among which the notion of the 'singing body' remains as yet noticeably under-theorised.

\section{A brief overview of gendered discourse in Disney's Princess films}

The 'Perfect Princess' films were made during Walt Disney's own lifetime and under his own direction. These establish as norm a gendered rhetoric to which all of the subsequent princess films have been obliged to respond in one way or another, namely, one wherein "female characters are almost always placed in competition with each other or, even worse, are presented as bitter enemies with one woman out to destroy the other" (Hollinger 2007: 76).

The 'Perfect Princess' might arguably be seen as Disney's own idea of the Ideal Feminine: a model domestic woman who is essentially a mother waiting (or wanting) to happen. As May notes:

His princess is sweet, has a talent (singing), works hard, and wants more than anything to marry and settle down. She is the earth mother whose love of animals and general kindhearted nature fills the queen (or queen-like figure) with rage (May 1981: 467).

Snow White, Cinderella and Aurora are almost identical in character. All three are depicted as subjugated, having been denied their true status in life, yet resigned to their fate and facing up to it with remarkable equanimity. Dressed in rags, they cook and clean with a song in their hearts. Herein, these narratives tell us, lies their true virtue and nobility. Their uncanny ability to commune with the creatures of nature is offered as proof of their goodness, marking them as the 'noble savage's. Accordingly, their nobility should be understood to lie not in the fact that they are born into that social class (as Aurora and Snow White are, but in fact as Cinderella is not), but that they are deserving of that status because they are virtuous. In this sense the 'Perfect Princess' is more strongly aligned with

3 The noble savage is a literary stock character expressing the idealised 'other' who has not been corrupted by civilisation, and therefore symbolises humanity's innate goodness. Featured strongly as an idealised concept in 18th-century Sentimentalism, it was subsequently also foregrounded in many $18^{\text {th }}$ - and $19^{\text {th }}$-century comic opera plots, the latter - as will be further argued in this article - being an important precursor for the narrative strategies employed in Disney's princess films. One such operatic example may be found in Niccolò Piccinni's comic opera about the servant girl Cecchina, entitled La buona figliuola (1760) and based on the prototype of the English sentimental novel, Samuel Richardson's Pamela, Or Virtue Rewarded (1740). 
the servant class than with the aristocracy, and her 'happily-ever-after' ending in the prince's castle becomes the "rags to riches" (Mollet 2013: 114) tale of the American Dream4 4 . The culture of abundance that typified the 1920s had given material backing to that dream, but the Stock Market Crash of 1929 and the Great Depression of the 1930s had brought widespread poverty in its wake. When hard times were upon them "the values of equality and democracy came under attack. The people of the United States looked for answers. Nothing was more influential for providing these answers than movies ... movies in the 1930s were near to the operative center of the nation's consciousness" (Ibid: 112). In this context Disney's success may be seen to rest, at least in part, on his ability to "tap into the spirit of the times" (Ibid: 113), champion the cause of the 'little person' - the societal other - and to fashion for him or her an escape into a glorious technicolour utopia wherein anything was both plausible and possible.

On the other hand, the princess's nemesis - a surrogate maternal figure who is the proverbial 'Evil Queen' - is ambitious, jealous, spiteful and narcissistic, as were many affluent Americans of the 1920s. Her power over nature is obtained through dark magic and used towards her own selfish ends. Because the ends she seeks lie "outside the ordinary course of nature" (Diderot in Canon 2012: 71) however, her behaviour becomes self-destructive and her doom is inevitable. A powerful woman, these films seem to suggest, is unnatural, thus it is her very power over nature that must be her final undoing.

Studies focused on the princess films of the so-called Disney Renaissance ${ }^{5}-$ those surrounding the decade of the 1990s - generally acknowledge the efforts the Disney company has made to invest the modern Disney princess with greater contemporary social relevance, particularly as regards discourses of gender and ethnicity, yet remain critical of the "quasi-liberal sentiments" that merely "grace the surface" (Ross 2004: 53) of these films. Ross thus applauds the fact that, with

$4 \quad$ At about the same time as filmmakers like Disney were setting out to establish their film studio empires, James Truslow Adams first coined the term "American Dream", describing it as one wherein "life should be better and richer and fuller for everyone, with opportunity for each according to ability or achievement [...] regardless of the fortuitous circumstances of birth or position" (Adams 1931: 214-215).

5 Walt Disney died in 1966. The last princess film to be made during his lifetime had been Sleeping Beauty in 1959, and it would be three decades before those who had taken over the reins of his company chose to revive the Singing Princess by way of The Little Mermaid in 1989. Their decision to do so met with an overwhelmingly positive audience response and resounding financial success, and was largely responsible for ushering in the era of the Disney Renaissance. The Disney Renaissance (Puig 2010) is the era from 1989 to 1999 during which Disney Studios experienced a creative resurgence in producing successful animated films based on well-known stories, which restored public and critical interest in the company as a whole. 
"Ariel's anthem of independence in The Little Mermaid, one is apt to feel girls have come a long way" (Ibid: 58), yet concludes that the promising signs of Ariel's initial "feminist rhetoric" are ultimately "undercut by the more conservative elements in her movie" (Ibid: 53):

Whatever Ariel might say, or sing, what we see her do is flee a world of infinite possibility to settle in the land of the banal. Her fantasy is a sort of anti-fantasy. Yes, she gets her legs, she makes her stand, she marches - but only down the aisle, to marry some guy named Eric. Many fairy tales, and many more movies, end with a wedding, and for this reason they often draw censure from critics [...] who would like to see our daughters presented with other options (Ibid: 60).

In similar fashion, Brocklebank (2000) hails Disney's cross-dressing Mulan as "the most radical form of the transformation motif, for she contravenes not just social rules but 'natural' 'fact'. The cross-dressed woman, with her illusion of 'maleness,' often reveals the arbitrary and cultural - or fictional - nature of gender inscriptions, and the instability of related codes and categories" (Brocklebank 2000: 273). Yet these same "social rules" are reinscribed in the film's ultimate "return to proper roles [...] moving toward a closure which contains or even quells any threateningly subversive representation" (Ibid).

Disney's attempts at the ethnic diversification of the Singing Princess have met with equally mixed reactions. In this regard Pocahontas has been the subject of particular scrutiny. Kilpatrick is sceptical of the success with which this film achieves genuine ethnic transformation, concluding that "instead of progress in depicting Native Americans, this film takes a step backwards - a very dangerous step because it is so carefully glossed as 'authentic' and 'respectful'" (Kilpatrick 1995: 36). To this Edwards adds her critique of the extent to which the film "writes racial mixture onto Pocahontas's body" so that Pocahontas becomes "an anachronistic image composed of 'aesthetically-pleasing' body parts drawn from American Indian, African American, Asian American, and Caucasian models" (Edwards 1999: 151), so allaying a "new anxiousness concerning the possible disappearance of whiteness in multiculturalism, whiteness both as a racial category and the dominant Anglo-American culture within pluralism" (Ibid: 149).

Three recent Disney princess films of the post-Renaissance period Enchanted (2007), Brave (2012) and Frozen (2013) - distinguish themselves from their predecessors for the more deliberately problematised manner in which the Singing Princess as filmic trope is presented, thus for the extent to which we are confronted with a somewhat 'Deconstructed Diva'. 
Parody permeates the film Enchanted when the animated characters of the fairy tale kingdom of Andalasia burst into the real world and the 'classic' Disney scenario begins to play itself out in New York City. Juxtaposed with the everyday working lives of modern-day New York citizens, its narrative recipe is exposed as nothing short of bizarre and ludicrous. In the real-world urban environment, Giselle learns that what you get for summoning the animals to help you clean house are not the cute and lovable forest creatures that helped Snow White, but cockroaches, sewer rats and mangy pigeons. And what cleaning entails in the real world is not exactly the romanticised affair that Snow White made it out to be, but "hairballs in the shower", "soap scum" and "scrubbing toilets". In the real world, love isn't a matter of a mere primal cry - "Ah!" - overheard by the prince as a voice-off, causing him to fall instantly in love and proposing marriage the very next day. Instead, in the real world people go on dates to get to know each other first. Love takes time. Sometimes relationships sour, and people get divorced. In the real world, furthermore, credit cards can do the work of fairy godmothers when ball gowns are needed in a hurry. Giselle's growing awareness of the real world culminates in her ultimate choice to remain in $21^{\text {st }}$ Century New York City, settle for a suburban life with divorcé Robert and open a shop, rather than to return with Prince Edward to the animated fairy tale world of Andalasia. The myth of an existence as 'Perfect Princess' is thus exposed for what it is: mere myth.

Or is it? Giselle may have chosen otherwise, but Robert's fiancée Nancy, the epitome of the modern, independent, professional New York woman, seizes her opportunity to opt out of the real world instead: with the two girls having swapped men, as it were, Nancy finds her 'happily-ever-after' with Prince Edward in Andalasia. In Enchanted's ending we are thus confronted with the characteristic double logic - the both/and rather than the either/or - of poststructuralism in general and of deconstruction in particular, revealing the "ambiguities", "equivocations" and "contradictions" (Holland 2016) of its text.

Brave's headstrong Princess Merida wants nothing more than to be out on the Scottish Highlands on horseback, wild and free, while her mother persists in attempting to teach her to be a refined lady and preparing her for marriage. The animosity that typically manifests in Disney's princess films between virtuous princess and evil queen, ultimately culminating in the happy marriage of the former and the doom of the latter, is thus given a quite different interpretation here. Here we encounter a princess who breaks the mould not only by refusing to find a man and settle down, but also by acting for the first time as the instigator and perpetrator of the trouble between the two women. This may be understood 
for its association with the broader theme of abjection in this film. Among other thing's, abjection, as Julia Kristeva explains it,
[...] confronts us [...] with our earliest attempts to release the hold of the maternal entity [...] It is a violent, clumsy breaking away, with the constant risk of falling back under the sway of a power as securing as it is stifling. [It arises from] the prohibition placed on the maternal body (as a defence against autoeroticism and incest taboo). [...] [ $\mathrm{tt}]$ represses the chora and its eternal return. Desire alone will henceforth be witness to that "primal" pulsation. [...] It takes the ego back to its source in the abominable limits from which, in order to be, the ego has broken away - it assigns it a source in the non-ego, drive, and death (Kristeva 1982: 13; 14; 15).

Merida's revolt against all that her mother stands for drives her to commit the ultimate act of abjection: poisoning her with enchanted cake, transforming the maternal body into that of a wild bear, thus relegating her to the status of the cursed, hunted bear Mor'du. Once this abjection is complete, however, and her mother faces almost certain death, does she become the "lost object" (Lacan 1977: 278), the "eternal return" (Kristeva 1982: 14), for which Merida grieves.

Deconstruction of the dichotomy between the Disney princess and her nemesis reaches its ultimate manifestation in Frozen. The film presents Elsa first as princess, then as queen. As Snow Queen her magical, 'unnatural', cryokinetic powers have the ability to destroy life. As princess she shrinks back, isolating herself from the world and renouncing her powers. But Elsa is simultaneously virtuous virgin and evil nemesis. This is a duality from which she cannot escape. At first she tries to deny the destructive side of who she is, then gives herself over to it and tries to deny her virtuous side. Only at the film's end does she finally find a way of living with both of these sides of who she is, to the benefit of herself and all of those around her. Thus, with Elsa it becomes clear that Disney's evil nemesis exists only insofar as his virtuous virgin exists: they are in fact two dimensions of one and the same feminine subjectivity. Psychoanalysis as a discipline casts light on such a state of affairs, for "the moral drama of psychoanalysis" is one wherein "the battle of the human subject is permanently being waged" (Bowie 1991: 21).

Freud describes the two opposing sides in this battle as the super-ego and the id. The id is "the dark, inaccessible part of our personality [...] a chaos, a cauldron full of seething excitations" (Freud 1933: 105), whereas, in terms of the Oedipus complex (where the child retreats from the mother before the power and authority of the father), the super-ego develops as a symbolic internalisation of the father and of cultural norms, "causing us to feel guilt if we contravene these norms" (Ibid: 78). But even as Elsa revels in the release of her long-repressed id and its "seething excitations", she witnesses the destruction she has caused by bringing an eternal winter upon her kingdom as a result, and flees to the 
mountains to escape the recrimination and guilt. She does not (cannot) remain there indefinitely however: the "moral drama" is merely exacerbated when it leads her to mortally injure her sister, who has come in search of her. It is at this point that Elsa realises the dangerous consequences of assuming her own desire without regard for the consequences.

Reconciliation of the eternal battle between Singing Princess and her nemesis thus ultimately lies in acceptance of the "reality principle" which is to be found in Freud's notion of the ego, whose purpose is to appease the id's drive in ways that will not be harmful or bring grief (Freud 1933: 110). And this is the reconciliation we witness in Elsa at the end of the film, by which means, one might argue, she imparts to all members of her trope a long-sought suturing of her feminine subjectivity.

But yet again, in true deconstructivist spirit, a double logic - a both/and rather than an either/or - manifests in Frozen's ending: lest we find Elsa's emancipation too alienating and the myth of Disney's own Ideal Feminine in danger of being forever dispelled, the film presents us with an alternative in the person of her sister Anna, whose character and life choices remain true to those of the 'Perfect Princess' in almost every respect.

\section{Theorising the singing body}

From the brief overview provided above, a trajectory emerges in which promising signs of a gradual process of social emancipation may be discerned: over the span of the 76 years of her existence we see Disney's princess transformed from one who is always virtuous and never evil, and who has no other desire or purpose but to be a wife and mother, to one who knows her own strengths and weaknesses, her good side and her bad, and who no longer needs a man in order to feel fulfilled.

Notably absent from this rhetoric, however, is any consideration of why the princess should need to be equipped with a singing talent in particular. In addition, as intimated in the introduction to this article, although the number of works devoted to discourses of the body in psychoanalytic film theory is vast indeed - certainly too vast to be adequately accounted for here ${ }^{6}$ - the notion of the 'singing body' has thus far received little, if any, attention in these works.

6 Among many others, these include, for example: Chamarette J (2015) Embodied Worlds and Situated Bodies: Feminism, Phenomenology, Film Theory. Signs: Journal of Women in Culture and Society 40(2): 289-295; De Lauretis T (1987) Technologies of Gender: Essays on Film, Theory and Fiction. Bloomington: Indiana University Press; Mellencamp P (1981) Made in the Fade. Cine-Tracts 3(4): 1-18; Olivier B (2012) Different 'percepts' of the human body in cinema. South African Journal of Art History 27(2): 79-97; Penley C (1988) Feminism and Film Theory. New York: Routledge; Williams L (1981) Film Body: An Implantation of Perversions. Cine-Tracts 3(4): 19-35; Lindner K (2012) Situated Bodies, Cinematic Orientations: Film and Queer Phenomenology. In Matyba S and Higbee W (eds) De-Westernizing Film Studies. London: Routledge, pp. 152-165; Cohan S and Hark IR (eds) (1993) Screening the Male: Exploring Masculinities in Hollywood Cinema. New York: Routledge. 
In order to consider that vital aspect of gendered discourse that emerges from an understanding of the Disney princess as 'Singing Princess', three points of view are put forward here:

- Psychoanalysis and psychoanalytic film theory in general, with particular consideration given to Julia Kristeva's Semiotic signifying disposition (Kristeva 1984) and Kaja Silverman's notion of the "acoustic mirror" (Silverman 1988).

- Claudia Gorbman's distinction between three types of musical codes operative in the filmic narrative (Gorbman 1987).

- The innamorata as trope, which the genre of the film musical inherited from musical theatre, operetta and comic opera, but which these theatrical forms, in turn, inherited from $16^{\text {th }}$ and $17^{\text {th }}$ Century Commedia dell'Arte.

Whereas psychoanalytic film theory was initially largely focused on developing an understanding of the various means through which cinema constructs the spectator as subject through confrontation with the filmic image (Hayward 2000: 300-301), post-structuralist cinema studies have increasingly tended away from such concerns towards an understanding not of cinematic pleasure but of subjective jouissance, thus of desire and fantasy. Whereas pleasure derives from a closure or suture of the Lacanian Imaginary and the Symbolic in the filmic experience, jouissance derives from the "extra-discursive", from the "enjoying body" and from "modes of narration that do not provide closure" (Ibid: 303). It is in this latter sense, therefore, that this article concerns itself with questions pertaining to the role that the voice, in particular, plays in facilitating experiences of the "extra-discursive" and the "enjoying body".

Julia Kristeva's import reaches film theory via linguistics. Her Revolution in Poetic Language (1984) challenges Freudian and Lacanian understandings of language as resorting exclusively within the domain of the paternal Symbolic. Rather, Kristeva maintains, language - and poetic language in particular - is always a synthesis of the paternal Symbolic and what she calls the maternal Semiotic, through which means it is "drawn out of its symbolic function [...] opened out within a semiotic articulation", and, "with a material support such as the voice", bring's "music" to literature (Kristeva 1984: 63). 
Kaja Silverman's The Acoustic Mirror?: the Female Voice in Psychoanalysis and Cinema (1988) draws various lines of enquiry together in a manner highly suggestive for and applicable to the subject matter of this article. What is at stake here, among other things, is the extent to which film "deposit[s] the female body into the female voice", so setting up "a psychic order to which its 'owner' is confined" (1988: 61). And it is out from under this position of confinement that female subjectivity must emerge in order to take up its place as "authorial voice" (Ibid: 187).

Valuable insights into the narrative strategies of film music can be gleaned from a number of scholars in this field. Of these, the work of Claudia Gorbman has been widely recognised for its significant and pioneering attempts to suggest a theory of musical narrative gesture for the Symbolic order of film that transcends "purely musical" coding to encompass also an understanding of "cinematic musical" coding, and ultimately of "cultural musical" coding (Gorbman 1987: 2-3). In this sense Gorbman's understanding of the layers of musical meaning that unfold in the filmic narrative are not unlike the nuances of signification that Roland Barthes suggests, for example, in his distinction between denotation, connotation and cultural myth (Barthes 1977: 15-51; 1987: 115).

A further insight into the musical nature of the Disney films that are the subject of analysis here derives from an understanding of the genealogy of the musical as film genre; its links to musical theatre, its connections to $18^{\text {th }}$ - and $19^{\text {th }}$-Century comic opera, as well as the extent to which all of these musical forms draw from the basic scenarios, character depictions, musical idioms and social functions of the $16^{\text {th }}$ - and $17^{\text {th }}$-Century Commedia dell'Arte (Darius 1996; Meagher 2000; Wilson 2010; Grout 1988; Cannon 2012; Pirrotta 1955). Unlike European film of the early $20^{\text {th }}$ Century, Hollywood never aspired to making of the filmic medium one of high art. From the very outset, Hollywood's "culture industry", as Adorno and Eisler disparagingly described it (Adorno and Eisler 1947: xxiii), was a capitalistic concern that thrived on mass appeal. In this regard, Walt Disney was no different to the rest of the filmmakers of early Hollywood. And for this purpose he turned to a tried and tested recipe for mass appeal: the

7 In psychoanalysis, the mirror phase is associated with the Lacanian Imaginary. See Lacan's essay entitled "The Mirror Stage as Formative of the Function of the I as revealed in Psychoanalytic Experience" in Lacan 1977: 1-8. But whereas Lacan associates the Imaginary with the visual mirror, theorists such as Silverman (1988) assume the auditory to be far more fundamental to the formative stages of subjectivity than the specular (the infant can hear long before it can see), hence the "acoustic" mirror. 
same recipe in fact that had, for the previous 500 years, ensured the popular success of the Commedia dell' Arte and comic opera ${ }^{8}$.

From this point of view, the basic plots and character portrayals in Disney's princess films may be seen to resort in the same three categories as do those of their predecessors, namely:

- The vecchi, in Disney's case mostly comprising evil Queens and stepmothers, or parental figures who are either uncompromising, or inept, or often entirely absent. The vecchi prevent the happy union of the lovers either because they are intent upon their own selfish ends, or because they are simply too selfabsorbed to be of any use to them.

- The zanni, where the masked clowns of the Commedia become in Disney's case 'masked' as creatures of nature, or as those existing on the outskirts of civilised society. As ever, their purpose in the narrative is not only to provide for comic relief, but also to aid in the cause of the innamorati.

- The innamorati, the central characters around whom the narrative unfolds, the Singing Princess and her beloved prince. Accordingly, Disney's Singing Princess may be understood to have emerged as a particular manifestation of the innamorata of the traditional Commedia and comic opera, and the genealogical precedents thus set provide a significant context against which to measure her trajectory over the course of the films analysed in this article.

\section{The Singing Princess in the acoustic mirror}

How the princess sings is integral to an understanding of the veritable language of each of the Disney princess films. As "pure musical code" (Gorbman 1987: 13), the sound of the Singing Princess's voice acts at the level of what Barthes has called the "grain" or "geno-song", which is "that apex (or that depth) of production where the melody really works at the language - not at what it says, but the voluptuousness of its sounds-signifiers" (Barthes 1977: 181).

In the case of the 'Perfect Princess' the Singing Princess is a soubrette; a light, sweet, lyrical soprano voice whose grain has inevitable intertextual associations with young, virginal operatic characters such as the servant girl Susanna in Mozart's

8 The Commedia scenario as basic narrative strategy is not unique to Disney. Many early Hollywood comedy classics rely on this same basic recipe, where the zanni are pitted against the vecchi, and where the narrative is designed to champion the cause of the zanni. The Marx Brothers films and the Bug's Bunny cartoons are but two examples hereof. Interestingly, both Groucho Marx and Bugs Bunny, exemplary zanni characters, rely on New York Bronx accents to mark their working class social status. 
The Marriage of Figaro or, in its more lyric coloratura guise, with innamorati such as Gilda in Verdi's Rigoletto. In the "voluptuousness of its sounds-signifiers" the grain of the soubrette voice transcends its role as "pure musical code" in order to function also as long-standing "cultural musical code" (Gorbman 1987: 13) for the virtuous, naïve, beautiful and therefore desirable woman. Her virtue lies in her unselfishness, her lack of interest in material wealth, her kind and loving nature, and her desire to be loved in return. She is as yet untouched by the ways of the world, and especially untouched by men. The soubrette voice is thus not only the age-old sonic embodiment of virtue as the "true model [...] of good" (Diderot in Cannon 2012: 72), but also, in Lacanian terms, the quintessential virginal Other; for, says Lacan, "such is the woman concealed behind the veil: it is the absence of the penis that turns her into the phallus, the object of desire" (Lacan 1977: 356).

Snow White's "I'm wishing", Cinderella's "A Dream is a Wish your Heart makes"10 and her "Sing Sweet Nightingale"11, and Aurora's "Once Upon a Dream"12 are all examples of 'Perfect Princess' songs that emphasise the lilting quality of the sweet soubrette sound, with scooped repeated notes and melodic leaps executed with exaggerated portamento. To offset this lilting quality, her coloratura voice - sung to a preverbal "Ah!" - serves as a gesture of unbridled longing that simultaneously underscores her ability to commune in a language understood by her zanni friends, the creatures of nature ${ }^{13}$.

What is notable in all of the scenes in which these songs are heard, is the stricken state in which the 'Perfect Princess' finds herself when she is driven to resort to song. Dressed in rags, Snow White and Cinderella are forced to scrub and clean, while Aurora, barefoot in the forest, searches for berries. The servile condition in which the diegesis presents her to us at these narrative moments is directly contrasted with the "voluptuousness of [her] sounds-signifiers" (Barthes 1977: 181), problematising the 'dissonance' between visual and musical codes, and reinforcing our belief in the privileged position she should by rights be instated into within the diegesis. This is particularly notable when seen and heard

9 The reader may view this scene and hear this song at https://www.youtube.com/ watch? v=KlUbWNpg10s (Accessed 12 May 2016).

10 The reader may view this scene and hear this song at https://www.youtube.com/ watch?v=KhTjnzlclel (Accessed 12 May 2016).

11 The reader may view this scene and hear this song at https://www.youtube.com/watch? v=F5qgEBHAVM (Accessed 12 May 2016).

12 The reader may view this scene and hear this song at https://www.youtube.com/ watch?v=3vtWyiTPq78 (Accessed 12 May 2016).

13 For examples of the 'Perfect Princess's' coloratura singing, the reader may view scenes from Snow White and the Seven Dwarfs at https://www.youtube.com/watch?v=hQZ6zzLpoNQ and from Sleeping Beauty at https://www.youtube.com/watch?v=N_8ZZ7jo6dw (Accessed 12 May 2016). 
against the privileged conditions at those same narrative moments of characters such as Cinderella's stepsisters, who sing very badly, or the nemesis vecchio characters, who can't sing at all.

In turning to a brief analysis of the lyrics of these songs in order to consider what the princess sings, it is notable that these all function as "cinematic musical codes" (Gorbman 1987: 13) for the outpouring of her desire. Born of castration, desire, according to Lacan, is ultimately a demand made to the Other that may be reduced in its essentials to "being a request for love" (Lacan 1977: 344). This is thus the 'Perfect Princess"'s wish, her dream, her fantasy. Snow White sings "I'm wishing for the one I love", while Cinderella echoes this wish when she sings "A dream is a wish your heart makes". Aurora addresses her fantasy prince directly when she sings, "I know you, I walked with you once upon a dream."

In addressing the question of why the 'Perfect Princess' sings, it has been noted that this genre of Disney film is a film musical with genealogical roots in the long tradition of related genres that began with the Commedia, continued through the $18^{\text {th }}$ and $19^{\text {th }}$ Centuries as comic opera and operetta, and manifested itself thereafter in lighter forms such as $20^{\text {th }}$ Century musical theatre and film musicals. This genealogy therefore provides one rather simple explanation for why she sings. Yet it does not explain why, in these particular narrative contexts, she must needs sing rather than any (or most) of the other characters. Her nemesis does not (cannot) sing; neither, for the most part, does the prince. When the zanni characters sing, as do Cinderella's mice for example, they do so mostly for comical effect.

The first reason, it seems, why she above all others must sing, lies in Kristeva's notion of the Semiotic. In the Symbolic (the narrative diegesis), the 'Perfect Princess' has no 'voice', no power to change her disavowed condition. The materiality of the singing voice thus serves, first and foremost, as a maternal surrogate, a discourse of the body which is her own lullaby, a means thus to take comfort in an "infantile scene" (Silverman 1988: 44) long denied her. The princess has no mother, or no mother whose presence has any bearing in her life. In addition, she is born to a weak or absent father. Although she began life as 'daddy's little girl', the father's love object, her wicked nemesis has long ousted her from that position. For this reason she is her own mother. In fact one might argue that she is all-mother. Her life of servitude requires this. Thus Mollet notes, for example, how "Snow White's preparation for motherhood is [...] prominent in Disney's retelling, through the way in which she cares for the dwarfs while staying with them" (Mollet 2013: 115). In addition to being the quintessential Madonna or all-mother figure (the Virgin Mary, untouched and pure, the Ideal Feminine), in fact, one might argue further that she represents a feminised sacrificial Christ-like figure, having no earthly father and therefore being simultaneously the all-father. 
Further to our understanding of the Semiotic discourse of the 'Perfect Princess' is the extent to which her singing functions as pre-linguistic mirror, a "jubilant assumption" (Lacan 1977: 2) that has the power to "tear open" (Kristeva 1984: 62) her words so that, as "musicalized text" (Ibid: 65), they permit the outpouring of her desire. What she 'sees' in this acoustic mirror is therefore not her impoverished and wanting circumstances, but her "Ideal-I", this being a form of self-identification associated with the mirror phase that "situates the agency of the ego, before its social determination", by which "the subject anticipates in a mirage the maturation of his power" (Lacan 1977: 2-3). Our first introduction to the ragged Snow White, for example, is not articulated through words, but through the tune she hums. As she continues in song, her aria develops into a duet with herself in the form of the echo of her voice coming back to her as she peers into the well. This reflection of her vocal image harmonises in third intervals as she sings, presenting a literal acoustic mirror. Further literal evidence of the acoustic mirror is found in Cinderella's "Sing Sweet Nightingale", where her reflections in the soap bubbles as she scrubs the floors, float "high above" in an act of transcendence, harmonising with her in a lyrical chromatic passage.

Another reason for presenting the 'Perfect Princess' as a Singing Princess is to be found in what Silverman calls film's tendency to want "synchronisation" of sound and image, in order to present a "compatibility of voice to body" (Silverman 1988: 48). Physical beauty and musicality become inextricably bound. As cultural musical code, the grain of the soubrette voice and its associations with virginal naïveté effect a process of "vocal corporealization" (Ibid: 61) to the extent that the voice itself becomes the object of the prince's sexual desire, his object a (Lacan 1977: 218).

There is thus an irony in the position in which the 'Perfect Princess' finds herself. On the one hand, "musicalized text" has empowered her to the point where she has been able to "tear open" the Symbolic and find her 'voice' in the Semiotic, an avenue for the outpouring of her desire. But in so doing, the process of vocal corporealisation now confines her to the body (Silverman 1988: 61). So she becomes a spectacle who is confined to "the inside of the narrative" (Ibid: 63), and who 'owes' us (and her prince) a performance. Both Snow White and Aurora's performances are first heard by the prince as a voice-off to which he is irresistibly drawn to secretly watch her and in fact spy on her. Herein is illustrated Silverman's understanding of the male gaze in film as one that occupies an extradiegetic, authoritative position that can be said to be "implied by a heightened faculty of audition - the capacity, as it were, to overhear" (Ibid: 54). By these means her voice becomes "doubly diegeticized, overheard not only by the cinema audience, but by a fictional eavesdropper" (Ibid: 57), with the "eavesdropper", moreover, ironically occupying a position in the Symbolic order, for which the Semiotic is a 'preparation' of sorts, but without guaranteeing entry into the Symbolic for the princess. 
This interiority to which the 'Perfect Princess' is confined establishes "the female body [as] the absolute limit of female subjectivity" (Ibid: 64). Her voice has only one function, to serve as an auditory image of her physical appearance, to attract her mate and therefore fulfil her role in his Oedipal trajectory. Silverman's referral to such a performance within a film as a "strip-tease" (Ibid: 62) is therefore not unfounded. Jones suggests that, although the vagina will be given pride of place, "the mouth is the starting point for female sexuality" while the female voice is little more than "the projection of the mouth" (Jones in Silverman 1988: 67), ultimately implying an equation of a woman's voice with her vagina. For this reason, it may be argued, the musical climaxes of the princess's performances in these three films - in particular her coloratura passages, sung to a preverbal "Ah!" - become erotic expressions of her fetishised vocal corporealisation, so underscoring Silverman's belief that "the female voice provides an acoustic equivalent of an ejaculation, permitting the outpouring or externalisation of what would otherwise remain hidden and unknowable" (Ibid: 68).

In the Renaissance films the Commedia narrative recipe begins to show signs of an altered dynamic between its typical characters. The zanni are no longer merely funny, cute, loveable, and helpful. They are elevated to the status of the sidekick who has a stronger presence and voice in the narrative, sometimes even a voice of dissent ${ }^{14}$, and who has a trajectory of his ${ }^{15}$ own to fulfil. Villainous vecchi and their henchmen also become far more nuanced characters than before. Instead of being purely evil, they are increasingly invested with comical characteristics that serve to paint them in a more sympathetic light ${ }^{16}$. Another significant new dimension to the recipe involves exploring the role of the innamorato in greater depth. Portrayed at times as a 'loveable rogue' capable of being reformed, even leading in some cases to a gender role-reversal in the recipe where his "ragsto-riches" (Mollet 2013: 114) trajectory rather than that of the princess is central to the narrative, it is now incumbent upon the innamorato to prove his virtue in order to win the hand of the princess and become a 'prince'17.

14 Sebastian in The Little Mermaid, Cogsworth in Beauty and the Beast, and Mushu in Mulan exemplify the sidekick zanni character who, although undying in his loyalty to the princess, does not hesitate to disapprove of her when he feels called upon to do so.

15 The princess's sidekicks are notably male rather than female.

16 For example, the sea witch Ursula in The Little Mermaid is a nemesis vecchio character who is not merely evil but also at times quite comical in her behaviour and appearance. lago in Aladdin and pug Percy in Pocahontas best exemplify the comical rather than purely evil henchman of the Disney Renaissance films.

17 Examples of films wherein the role of the innamorato is more strongly foregrounded are Beauty and the Beast, Aladdin, and Tangled. For more on aspects of gender role reversal in the films of the Disney Renaissance, see Self-citation 2014. 
Most central to these narratives, however, are the changes undergone by the princess herself. In this regard, a notable difference in how the princess sings is immediately apparent. Scored by Alan Menken, the Renaissance films rely on a musical style grounded in Broadway musical theatre of the late 1980s and 1990s, exemplified by its typical light belting quality of singing. While her voice remains a sweet soprano, sometimes bordering on the range of a mezzo-soprano, the Singing Princess is no longer the fragile soubrette she once was. Her style of singing is more powerful, anchored in nasal resonance. The 'Perfect Princess' has a demure and reserved vocal style: while her sound flows freely and with resonance, it is not 'projected' or propelled outward. By contrast the 'Renaissance Princess' sends out a ringing, rich, almost hurtled cry, flowing from her with full expression. Vibrato is another aspect of the tone that is treated very differently. While the 'Perfect Princess' produces an almost-excessive vibrato from the onset of the tone, the 'Renaissance Princess' maintains a straighter tone with tail-end vibrato. As "pure musical code" (Gorbman 1987: 13) this more piercing, nasal tone takes on the role of "cultural musical code" (Ibid), signifying a liberated princess, one with greater phallic attributes, one more liberated and vocally defeminised so that she may pursue the adventure she seeks. The melodic leaps of the past are still present; in their performance they are not connected through portamento, however, but are more forcefully belted - almost 'attacked' at the onset of the sound. In this manner vocal leaps take on the character of phallic musical gestures, with broken-chord figures, triplet figures, syncopated rhythmic figures and repeated-note statements of proclamation. As the princess is musically empowered, she is simultaneously de-feminised (gone are the frilly coloratura passages and the excessive vibrato of before), signifying her desire to pursue a dream that is more than merely the happily-ever-after of marriage and domesticity.

In turning to what the 'Renaissance Princess' sings, it is notable that the lyrics of these song's all call for liberation and equality. Ariel's call to be "part of that world"18 signifies a need for the princess to be accepted into a new world, one where she must learn to stand 'on her own two feet' and where she must fight for her voice to be heard. Rapunzel's "When will my life begin?"19 is much like Ariel's song in style and in its call to be part of a world to which the princess is forbidden to belong. Given the gender role-reversal in Aladdin, what we are presented with in this film is a 'Singing Prince' rather than a Singing Princess, with Jasmine remaining musically silent throughout most of the film. However, she does join

18 The reader may view this scene and hear this song at https://www.youtube.com/watch?v=nzx916MuL8 (Accessed 12 May 2016).

19 The reader may view this scene and hear this song at https://www.youtube.com/ watch? $=$ je4nDvNJXsg (Accessed 12 May 2016). 
Aladdin in song on one occasion, where their duet calls for gender equality in "a whole new world"20. Belle's call in Beauty and the Beast is for adventure "in the great wide somewhere", wanting "more than this provincial life"21. Pocahontas sings of the unpredictable nature of the river to which she is bound, rowing ahead to find the changes that lie in store "just around the river bend". ${ }^{22}$ Mulan dreams of a world not bound by gender norms, where she will be free to become the hero, allowing her mirrored reflection to show who she truly is inside. As she sings, she wipes away the painted mask of artificial femininity, castrates her true femininity by chopping off her hair, and dons her father's armour, becoming masculinised by the song's end ${ }^{23}$. In similar fashion Tiana's song "Almost there" 24 in The Princess and the Frog expresses her aspirations of owning her own restaurant, largely in order to realise her father's unfulfilled dreams. In both Mulan and Tiana we thus see the ultimate manifestation of the Singing Princess in her role as 'daddy's little girl', bordering on the Electra complex. ${ }^{25}$ In this way Disney "makes a man" out of the 'Renaissance Princess' as she embarks on the trajectory of the father with hard work, determination and 'masculine' single-mindedness.

In turning to the question of why the 'Renaissance Princess' sing's, all but one (Ariel) function almost exclusively as pre-linguistic mirror at the level of Kristeva's Semiotic, a "jubilant assumption" (Lacan 1977:2) in "musicalized text" (Kristeva 1984: 65) wherein she is permitted leisure to imagine and embrace the possibility of a world quite different to the one she currently inhabits, a world of endless opportunity where she is free to choose her own path. This is not a cry for a husband and marriage, but the cry of the new woman who seeks liberation from patriarchy. For this reason her songs are no longer overheard by a "fictional eavesdropper" (Silverman 1998: 57), instead actively resisting patriarchal attempts at restricting her to a situation wherein her body has become "the absolute limit of [her] subjectivity" (Ibid: 64). In this way these songs, all heard very close to the beginnings of the films in which they occur, participate in the ruse that ultimately plays itself out. By "luring audiences in with

20 The reader may view this scene and hear this song at https://www.youtube.com/watch? $v=-$ kl4hJ4j48s (Accessed 12 May 2016).

21 The reader may view this scene and hear this song at https://www.youtube.com/ watch?v=4SEr8VELvlo (Accessed 12 May 2016).

22 The reader may view this scene and hear this song at https://www.youtube.com/ watch?v=4DE5a80l8EU (Accessed 12 May 2016).

23 The reader may view this scene and hear this song at https://www. youtube.com/ watch? $v=5 A_{-}$ Rl8aQxII (Accessed 12 May 2016).

24 The reader may view this scene and hear this song at https://www.youtube.com/ watch? $\mathrm{v}=\mathrm{a} 00 \mathrm{abpVd5UI}$ (Accessed 12 May 2016).

25 According to Carl Gustav Jung's Neo-Freudian psychology, the Electra complex describes a girl's psychosexual competition with her mother for possession of her father. 
[musical]-fantasy bribes" (Hollinger 2007: 76), they cement a commitment to the emancipation the princess seeks, only to have her give it all up in the end to marry her prince and settle down. These "competing ideological positions" (Ibid) are the hallmark of the Disney Renaissance films. More than that, they appear to signal Disney's ultimate rejection of the possibility of real feminine emancipation: having experimented with it, it is rejected in favour of American family values.

Ariel in The Little Mermaid stands out from the remainder of the 'Renaissance Princesses' for the quite different function her voice fulfils. After saving the prince from certain drowning during a storm at sea, Ariel's heart is lost to him. Her song "Part of That World" is thus repeated as "Part of Your World", an expression of her new desire for marriage rather than for freedom and adventure. As she lovingly gazes upon the prince, prostrate on the beach, her voice draws him from his semi-conscious state sufficiently to hear it, but not to see or remember her face. He subsequently becomes fixated with that voice, obsessed with finding the one to whom it belongs. Ariel's voice thus takes on the power of the proverbial maternal voice - birthed in this instance from the ocean, the ultimate feminine space ${ }^{26}$ - this voice being "the first model of auditory pleasure", one that "assumes the status of a completely inaccessible object, of an object which not only remains unobtainable itself, but for which there can be no substitute" (Silverman 1988: 87). Ariel's subsequent bargain with the Sea Witch Ursula entails giving up her voice for the human form she seeks. Once human, therefore, she is mute, and, as it turns out, quite powerless to secure his affections as a result. Instead Eric shifts his fixation to Ursula herself, now transformed into human form and using Ariel's stolen voice as her own. By a last-minute intervention of her zanni friends, however, the amulet enclosing her stolen voice is returned to her, and her muteness is overcome. Only after her voice has been returned to her is the prince able to recognise Ariel as the object of his desire, securing the 'happily-ever-after' she seeks. Hence it may be argued that Ariel's fate in The Little Mermaid represents the most extreme instance of vocal corporealisation in this genre of film: narrative resolution comes only once the voice of the Singing Princess is re-confined to her body.

In the post-Renaissance period, on the other hand, each Singing Princess continues the trajectory of feminine emancipation in her own, atypical fashion, in the process of which the Commedia narrative recipe is increasingly undone. The music of Enchanted actively participates in a parody of Giselle's extreme

26 Connections made in psychoanalysis between the maternal and the oceanic may be found, for example, in the notion of the maternal chora as "watery receptacle" of life (Plato in Kristeva 1984: 26), in the notion of the "oceanic feeling" (Freud 1929) and in that of the "sonorous womb" (Rosolato 1969). 
virtuosity and naïveté, bordering on the ridiculous, with the three song's she sings all containing 'tongue-in-cheek' references to earlier Disney films. "True Love's Kiss"27 recalls the era of the 'Perfect Princess', modelled on Snow White's "I'm Wishing" and Cinderella's "A Dream is a Wish Your Heart Makes". To reinforce this intertextual reference and emulate the distinctive grain of the 'Perfect Princess' soubrette voice, singer-actress Amy Adams reports that she was coached to deliberately render the song in what she describes as "an operetta style". ${ }^{28}$ The song is first heard when the animated Giselle, still happily settled in her humble cottage in the woods of Andalasia, sings to her cute forest friends of the prince she awaits and the kiss that will seal their betrothal. Predictably, her song is also provided with a coloratura preverbal "Ah!", designed to instantly draw her dream prince to her side, and which she later re-uses to summon the animals of New York City to help her clean Robert's apartment.

The remaining two Giselle songs, "Happy Working Song" 29 and "That's How You Know" ${ }^{30}$, are rendered in a Broadway style, thus with a grain of voice typical of the 'Renaissance Princesses'. "Happy Working Song" recalls songs expressing joy in domestic chores, such as "Whistle While You Work" (Snow White and the Seven Dwarfs) and "The Work Song" (Cinderella). But whereas these models provide narrative contexts and song lyrics that idealise and trivialise domestic work, in New York City Giselle's "Happy Working Song" is offset against the realities of decidedly unpleasant domestic tasks and the vermin that come to assist her in it - she still dressed in her voluminous wedding dress since the previous day so that its relentless cheerfulness takes on an element of the ridiculous. "That's How You Know" is a self-parody of Menken's own earlier Broadway-style Disney compositions, such as "Under the Sea" (The Little Mermaid) and "Be Our Guest" (Beauty and the Beast), big production numbers with a set incorporating an ever-growing crowd of singers and dancers. On their walk through Central Park, Giselle bursts out into spontaneous song, describing to the cynical Robert what he should do to let a girl know that he loves her. Instead of her song acting as "striptease" (Silverman 1988: 62) that causes him to fall instantly in love, however, Robert reacts with extreme embarrassment that Giselle should make such a spectacle of herself (and of him) in public, and responds with "Oh no no ... People

27 The reader may view this scene and hear this song at https://www.youtube.com/ watch?v=1Vr8wU4aUsM (Accessed 12 May 2016).

28 See Adams' reflections on her preparations for this film at http://www.moviesonline.ca/ movienews_13467.html (Accessed12 May 2016).

29 The reader may view this scene and hear this song at https://www.youtube.com/ watch? v=ZrwxlypQisY (Accessed12 May 2016).

30 The reader may view this scene and hear this song at https://www.youtube.com/ watch?v=q7Z8IdVwK5Y (Accessed12 May 2016). 
looking ... Don't sing ... That's ok, you know, let's just walk". As the production number grows and passers-by all over Central Park come to join in, singing along in perfect harmony and dancing along in perfectly choreographed steps, Robert reacts with utter dismay: he simply cannot understand how everybody in Central Park suddenly knows this song.

Musically, Merida's refusal in Brave to be "confined" (Silverman 1988: 45) within the narrative, to be free to roam the wild countryside and to determine her own future, manifests in her refusal to render a song and dance performance within the diegesis. Abjection of the mother thus extends to abjection of the "sonorous womb" (Rosolato 1969). Instead she takes on the position of narrator, providing her own commentary on and interpretation of the events of the narrative, in which context she also renders two non-diegetic songs as voice-over in the course of the film. These songs, namely, are "Touch the Sky" ${ }^{31}$ and "Into the Open Air". 32 As "cinematic music signifier" (Gorbman 1987: 13), what she sings in "Touch the Sky" serves as "jubilant assumption" (Lacan 1977: 2) to endorse the sense of freedom she feels when she is alone in the forest, where no social expectations are placed upon her. In the case of "Into the Open Air", it serves to highlight a "friction" (Cook 1998: 16) between the abjected mother and Merida's growing sense of loss for the human mother now lost to her. Both songs are performed by Julie Fowlis (b.1979), Merida's off-screen singing voice, celebrated Scottish folk singer and multi-instrumentalist who is especially known for her Scottish Gaelic songs. The grain of Fowlis's voice lends a distinctive character to how the princess sings: unaffected, complete in its 'naturalness', with passages sung lightly and freely without any hint at great technical prowess or pretence, emphasising that her singing is 'earthy', uncontrived and unassuming. This is no vocal "striptease" (Silverman 1988: 62). She is not out to catch a man. In addition, Merida is not beautiful (at least not in the 'Barbie-doll' sense of the word), nor is she refined and well kempt. Her hair is wild and badly in need of a brush, her table manners are atrocious, and her dress invariably torn. In all of these respects she breaks the mould of the 'Perfect Princess'.

Thus there is a new reason why the princess sings. Investing in Merida's speaking and singing voice the status of voice-over is an important indication of the new sense of empowerment the princess is afforded, one never afforded her before now, so enabling what Pascal Bonitzer calls a "usurpation" of authority over the narrative:

31 The reader may view this scene and hear this song at https://www.youtube.com/ watch?v=gA9nZrhFo4U (Accessed12 May 2016).

32 The reader may view this scene and hear this song at https://www.youtube.com/ watch?v=XT3gSBCZjNc (Accessed12 May 2016). 
This is not, one suspects, without ideological implications.

The first of these implications is that the voice-off represents a power, that of disposing of the image and of what it reflects, from a space absolutely other with respect to that inscribed in the image-track. Absolutely other and absolutely indeterminant. Because it rises from the field of the Other, the voice-off is assumed to know: this is the essence of its power (Bonitzer 1986: 325).

In Merida we therefore encounter for the first time a Disney princess who resists a situation wherein the narrative "deposit[s] the female body into the female voice", so setting up "a psychic order to which its 'owner' is confined" (Silverman 1988: 61). In so doing the female subjectivity of the princess finally emerges out from under her traditional position of confinement in order to take up its place as "authorial voice" (Ibid: 187). Eschewing the reduction to "singing body', furthermore, implies that Merida claims a position in the Symbolic, but not the Symbolic in the ordinary sense, which is that of the axiological repository of a patriarchal social order. Rather, given that her voice-over singing happens in the forest, when she is away from other people, implies that she is minimally adumbrating a Symbolic order beyond the patriarchal, one in which woman also has a place.

In Frozen, Elsa's song "Let it Go"33 finally lets loose the "cauldron full of seething excitations" (Freud 1933: 105) inside of her. What she sings at this point thus acts as "cinematic music signifier" (Gorbman 1987: 13) for the triumphant release of pent-up tension within her own psyche. Instead of denying the Evil Queen within her, she is resolved to embrace her, renouncing the myth of the 'Perfect Princess' with her words "that perfect girl is gone". In turning to the question of why she sings, we might understand Elsa's song as an acoustic mirror experience that, in the words of Lacan, "is a drama whose internal thrust is precipitated from insufficiency to anticipation - and which manufactures for the subject [...] the succession of phantasies that extends from a fragmented body-image to a form of its totality" (Lacan 1977: 5). No longer does she sing for the benefit of a "fictional eavesdropper" (Silverman 1988: 57). She does not sing because she wants a man. Alone in the mountains, she sings to celebrate a new sense of her identity that society has long required her to repress. Her "musicalized text" (Kristeva 1984: 65) thus embraces the Semiotic character of the singing voice because it is precisely the Semiotic that has the power to "pulverise" the established order and to "make it a new device" (Ibid: 51).

33 The reader may view this scene and hear this song at https://www.youtube.com/ watch?v=moSFlvxnbgk (Accessed 12 May 2016). 
This new sense of empowerment is also manifest in how Elsa sings. The speaking and singing voice for Elsa in Frozen was provided by American actress and singer-songwriter Idina Menzel (b.1971). The grain of Menzel's well-known voice provides a distinctive intertextual association between the character of Elsa and those of other theatrical and filmic characters for which Menzel has gained considerable recognition. These typically include characters with a 'dark' side, such as Maureen Johnson in Rent (performed by Menzel both in the Broadway stage production as well as in the film of 2005) and Elphaba in the Broadway musical Wicked, a character she helped create. Menzel's voice is husky and at times strident in quality, classified best as a mezzo-belter in musical theatre terms. Her vocal line in "Let it Go" requires a great range, beginning (and remaining for the most part) extraordinarily low for a Disney princess, with top notes that are exceedingly belted. The huskiness of the lower register and the strident nature of the upper register give a sense of a truly liberated princess, exploring new vocal territory down below, while also crying out above in victory, finally liberated.

\section{Conclusion}

This article has followed a trajectory of Disney's Singing Princess in its analyses of three factors pertaining in the songs she sings: how she sings, what she sings, and why she sings.

In addressing the question of how the Singing Princess sings, the peculiar sonic qualities of the singing voice as "pure musical code" (Gorbman 1987: 13) were considered, insofar as its grain adds significant dimension to the "geno-song" of each film. This trajectory begins with the "Perfect Princess"'s lilting and hyperfeminine soubrette voice, modelled on the innamorata of the Commedia and comic opera, followed by the rebellious 'Renaissance Princess's' masculinisedfeminine musical theatre style of singing, typically required for the songs composed by Alan Menken, and ends with the 'Deconstructed Diva's parody of the former (Giselle), or the rendering of a disembodied, earthy, folk-style voiceover (Merida), and finally a mezzo-belter that combines theatrical and popular singing techniques (Elsa). This change in grain manifests as a "feminist rhetoric" (Ross 2004: 53) in its own right, a response to the way women in film are perceived and a manifestation of their growing sense of social emancipation. Regression to a more effeminate grain thus accompanies a narrative context wherein the princess has regressed to a position of social impotence, as is clearly seen (heard) with Rapunzel in Tangled, for example, who is largely confined within the narrative to the role of the traditional innamorata although, chronologically, she is a product of the most recent period in Disney's princess film history. 
What the Singing Princess sings was shown to comment upon the events of the filmic diegesis, thus to act as "cinematic music code" (Gorbman 1987: 13). The lyrics of songs of the 'Perfect Princess' make her desire for a prince explicit: he is her rescuer, her Knight in Shining Armour, whereas she is powerless to save herself. The 'Renaissance Princess' sings to express an initial desire for emancipation, the power to choose her own fate. The desire for a prince is merely implicit herein, never explicit, so that the viewer is swept along in the seemingly endless possibilities suggested by her initial song as "fantasy bribe" (Hollinger 2007: 76), only to find that she is not that rebellious after all, reverting in the end to the social boundaries of marriage. The 'Deconstructed Diva' resorts to parody (Enchanted), or to an exaltation of her freedom (Brave), or to embracing the "cauldron full of seething excitations" (Freud 1933: 105) within her, the latter traditionally reserved as the province of her nemesis (Frozen).

The princess's trajectory was also traced by following the changing answers to why she sings. In the case of the 'Perfect Princess', a number of reasons were identified. She sings, first and foremost, in her role as all-mother, to take comfort in her own lullaby, as when Snow White asks the little birds of the forest, "What do you do when things go wrong? Oh! You sing a song!" Secondly, she sings because the Semiotic pulsion represented in the materiality of the singing voice empowers her, providing an acoustic mirror experience of her "Ideal-l" (Lacan 1977: 2). Thirdly, she sings because she is bound by the Commedia recipe in which she functions to emulate her operatic precedents, wherein the grain of her soubrette voice must take on the role of "cultural musical code" (Gorbman 1987: 13) to mark her as the innamorata - the virginal, desirable woman. All of the 'Perfect Princesses', and including Ariel in The Little Mermaid, thus sing as a mating call, a vocal "striptease" (Silverman 1988: 62) - particularly in the guise of the coloratura pre-verbal "Ah!" as an "acoustic equivalent of an ejaculation" (Ibid: 68) - that is designed to attract the prince who, in order to respond to it, must needs be invested with a "heightened faculty of audition" (Ibid: 54). In this latter sense, therefore, she sings in order to re-enforce her role as mere spectacle, disempowered by her "confinement" to the body (Ibid: 61).

From the time of the 'Renaissance Princesses' onwards, the reason the princess sings begins to shed its purpose as mating call. Her singing gradually becomes a mirror experience no longer intended for the benefit of a "fictional eavesdropper" (Silverman 1988: 57) within the diegesis, but rather to express her desire for her own adventure. In this regard it was noted that the songs of the 'Renaissance Princesses' contribute to the "competing ideological positions" of the Disney Renaissance films, insofar as they "lur[e] audiences in" at the start of the narrative, only to find that the princess "recuperate[s] this progressivity for patriarchy by the film's end" (Hollinger 2007: 76). 
In the post-Renaissance period, Giselle in Enchanted sings in order to poke fun at the very idea of the innamorata, while Elsa's singing in Frozen deconstructs in "a double movement of simultaneous affirmation and undoing" (Holland 2014) the "competition" and the will to "destruction" (Hollinger 2007: 76) in the feminist rhetoric of Disney's princess films, by voicing the "rage" (May 1981: 467) of the queen in the 'singing body' of the princess. Merida in Brave brings about the most complete emancipation of the feminine voice when the princess's body is no longer presented as a diegeticised singing body. "To embody a voice is to feminise it" says Silverman (Silverman 1988: 49), or to identify it with a sense of mortality or lack. Now the princess finally emerges "out from under" the position of vocal corporealisation to take up a phallic position traditionally assigned to her male counterpart, aligning her with "the gaze, the phallus, and what exceeds synchronisation" (Ibid: 50), thus "with the apparatus (camera or microphone) and with a transcendental position of power" (Ibid: 56-57).

Such promising signs of emancipation notwithstanding, the fact that the Disney princess remains a Singing Princess, after all is said and done, is not without contrary significance. While she continues to find recourse in the Semiotic register of her "musicalized text" (Kristeva 1984: 65), to "tear open" (Ibid: 62) the Symbolic world in which she operates, to "pulverise" it, and make it a "new device" (Ibid: 51), and while this pulverisation functions first and foremost as the source of her avowal, ironically it is always also the source of her disavowal, since in so doing the "materiality of the [singing] voice" continues to mark her discourse as inevitably and irreducibly "feminine" (Ibid: 63). From this dilemma she cannot escape. However much Disney may wish to plead a position of neutrality as far as issues of gender are concerned, therefore, the princess films remain "an influential purveyor of gendered images", whereas "the influence of this cinematic representation of femininity reach[es] far beyond the limits of the theater and extend[s] past the confines of a child-centered audience" (Brocklebank 2000: 270). For its pervasiveness alone, if not for its surreptitious appearance in the guise of fantasy and fairy tale, the Singing Princess as filmic trope asks our serious consideration.

\section{Bibiography}

AdAms JT (2001 [1931]) The epic of America. New York: Simon Publications.

ADORNO TW AND EISLER H (2004 [1947]) Composing for the films. Intro. G McCann.

New York: Athlone Press.

BARTHES R (1977) Image, music, text. London: Fontana.

BARTHES R (1987 [1957]) Mythologies. New York: Hill and Wang. 
BONITZER P (1986) The silences of the voice. In Rosen P (ed) Narrative, apparatus, ideology: a film theory reader. New York: Columbia University Press, pp. 319 $-334$.

BoWIE M (1991) Lacan. London: Fontana Press.

Brocklebank L (2000) Disney's 'Mulan' - the 'true' deconstructed heroine? Marvels and Tales 14(2): 268-283.

Cannon R (2012) Opera. Cambridge introductions to music. Cambridge: Cambridge Univerity Press.

Соок N (1998) Analysing musical multimedia. Oxford: Clarendon Press.

DarIUS A (1996) The Commedia Dell' Arte. Helsinki: Kolesnik Production OY.

EDWARDS LH (1999) The united colors of 'pocahontas': synthetic miscegenation and disney's multiculturalism. Narrative 7(2): 147-168.

FREUD S (1995 [1933]). new introductory lectures on psychoanalysis. New York: Norton.

FreUd S (2011 [1929]) Civilization and Its discontents. Mansfield Centre: Martino Publishing.

GROUT DJ (1988) A short history of opera, 3rd edition. New York: Columbia Univerity Press.

GORBMAN C (1987) Unheard melodies: Narrative film music. Bloomington: Indiana University Press.

HaYWARD S (2000) Cinema studies: The key concepts. London: Routledge.

HoLLAND NJ (2016) Deconstruction. Internetencyclopedia ofphilosophy. <http:// www.iep.utm.edu/deconst/> Accessed 13 March 2016.

HOLLINGER K (2007) 'Good girls and wicked witches: Women in Disney's feature animation' by AM Davis (Review Article). American Studies 48(2): 75-76. https://doi.org/10.1353/ams.0.0057

KILPATRICK J (1995) Disney's 'politically correct' 'Pocahontas'. Cinéaste 21(4): 36-37.

KRISTEVA J (1982) Powers of horror: an essay on abjection. Trans. LS Roudiez. New York: Columbia University Press.

KRISTEVA J (1984) Revolution in poetic language. Trans. M Walker, Intro. LS Roudiez. New York: Columbia University Press.

LACAN J (1977) Écrits: A selection. Trans. A Sheridan. New York: Norton.

LAKOFF G AND JOHNSON M (1980) Metaphors we live by. Chicago: University of Chigaco Press.

MAY JP (1981) Walt Disney's interpretation of children's literature. Language Arts 58(4): 463-472. 
MeAgher J (2000) Commedia dell'Arte. Heilbrunn timeline of Art History. New York: The Metropolitan Museum of Art. <http://www. metmuseum.org/toah/ hd/comm/hd_comm.html> Accessed 3 August 2014.

Mollet T (2013) 'With a smile and a song...': Walt Disney and the birth of the American fairytale. Marvels and Tales 27(1):109-124. https://doi.org/10.13110/ marvelstales.27.1.0109

PIRRotTA N (1955) Commedia dell'Arte and Opera. The Musical Quarterly 41(3): 305-324. https://doi.org/10.1093/mq/XLI.3.305

Potgleter L (2014) Deconstructing Disney's divas: a feminist psychoanalytic critique of the singing princess. Unpublished masters' thesis. Nelson Mandela Metropolitan University, South Africa.

PUIG C (2010) 'Waking Sleeping Beauty' Documentary takes animated look at Disney Renaissance. USA Today, 26 March 2010. <http://usatoday30. usatoday.com/life/movies/reviews/2010-03-26-beauty26_ST_N.htm> Accessed 11 November 2014.

Rosolato G (1969) La Voix. Essais sur le symbolique. Paris: Gallimard.

Ross D (2004) Escape from Wonderland: Disney and the female imagination. Marvels and Tales 18(1): 53 -66. https://doi.org/10.1353/mat.2004.0016

SILVERMAN K (1988) The acoustic mirror: The female voice in psychoanalysis and cinema. Bloomington: Indiana University Press.

WILSON MR (2010) A history of Commedia dell'Arte. Faction of Fools Theatre Company Inc. <http://www.factionoffools.org/history> Accessed 3 August 2014.

\section{Filmography}

Aladdin

Beauty and the Beast

Brave
(1992). Directed and produced by Ron Clements and John Musker. A Walt Disney Pictures and Walt Disney Feature Animation Film. Distributed by Buena Vista Pictures.

(1991). Directed by Gary Trousdale and Kirk Wise. Produced by Don Hahn. A Walt Disney Pictures and Walt Disney Animation Film. Distributed by Buena Vista Pictures.

(2012). Directed by Mark Andrews and Brenda Chapman. Produced by Katherine Sarafian. A Walt Disney Pictures and Walt Disney Animation Film. Distributed by Walt Disney Studios Motion Pictures. 
Cinderella

Enchanted

Frozen

Mulan

Pocahontas

Sleeping Beauty

Snow White and the Seven Dwarfs

Tangled

The Little Mermaid
(1950). Directed by Clyde Geronimi, Hamilton Luske and Wilfred Jackson. Produced by Walter Disney. A Walt Disney Productions Film. Distributed by RKO Radio Pictures, Inc.

(2007). Directed by Kevin Lima. Produced by Barry Josephson and Barry Sonnenfield. A Walt Disney Pictures and Josephson Entertainment Film. Distributed by Walt Disney Studios Motion Pictures. (2013). Directed by Chris Buck and Jennifer Lee. Produced by Peter Del Vecho. A Walt Disney Pictures and Walt Disney Animation Studios Film. Distributed by Walt Disney Studios Motion Pictures.

(1998). Directed by Tony Bancroft and Barry Cook. Produced by Pam Cook. A Walt Disney Pictures and Walt Disney Feature Animation Film. Distributed by Buena Vista Pictures.

(1995). Directed by Mike Gabriel and Eric Goldberg. Produced by James Pentecost. A Walt Disney Pictures and Walt Disney Feature Animation Film. Distributed by Buena Vista Pictures.

(1959).Directed by Clyde Geronimi, Les Clark, Eric Larson and Wolfgang Reitherman. A Walt Disney Productions Film. Distributed by Buena Vista Pictures.

(1937). Directed by William Cottrel and David Hand. Produced by Walter Disney. A Walt Disney Productions Film. Distributed by RKO Radio Pictures, Inc.

(2010). Directed by Nathan Greno and Byron Howard. Produced by Roy Conli, John Lasseter and Glen Keane. A Walt Disney Pictures and Walt Disney Animation Studios Film. Distributed by Walt Disney Studios Motion Pictures.

(1989). Directed by Ron Clements and John Musker. Produced by John Musker and Howard Ashman. A Walt Disney Pictures and Walt Disney Feature Animation Film. Distributed by Buena Vista Pictures. 
The Princess and the Frog
(2009). Directed by Ron Clements and John Musker. A Walt Disney Pictures and Walt Disney Animation Studios Film. Distributed by Walt Disney Animation Studios. 